\title{
Chemical composition of wonderful kola (Bucchlozia coriacea) and breadfruit (Artocarpus altilis) seeds grown in south-south, Nigeria
}

\author{
M. O. Aremu ${ }^{1 *}$, D. B. Passali ${ }^{1}$, H. Ibrahim ${ }^{2}$ and R. O. Akinyeye ${ }^{3}$ \\ ${ }^{1}$ Department of Chemical Sciences, Federal University Wukari, PMB 1020 Taraba State, Nigeria \\ ${ }^{2}$ Department of Chemistry, Federal University Lafia, PMB 146, Nasarawa State, Nigeria \\ ${ }^{3}$ Department of Chemistry, Ekiti State University, PMB 5363, Ado-Ekiti, Nigeria
}

Received: 16 June 2017

Revised: 14 May 2017

Accepted: 29 May 2017

DOI: http://dx.doi.org/10.3329/bjsir.v53i2.36673

\begin{abstract}
The proximate and amino acid compositions of Artocarpus altilis and Bucchholzia coriacea were investigated using standard analytical techniques. The respective proximate composition (\%) for the Artocarpus altilis and Bucchholzia coriacea samples were: Moisture (5.91 and 5.67); ash (4.39 and 5.13); crude fat (4.42 and 2.76); crude protein (12.27 and 14.78); crude fibre (7.10 and 6.27); carbohydrate (65.91 and 65.39). The calculated fatty acids and metabolizable energy for the Artocarpus altilis and Bucchholzia coriacea samples were 3.54 and $2.21 \% ; 1492.60$ and 1465.01 $\mathrm{kJ} / 100 \mathrm{~g}$, respectively. The most abundant minerals in Artocarpus altilis and Bucchholzia were potassium (658.42 and $369.64 \mathrm{mg} / 100 \mathrm{~g}$ ) and phosphorus (382.55 and $261.38 \mathrm{mg} / 100 \mathrm{~g}$ ), respectively. The amino acid profile revealed that Artocarpus altilis and Bucchholzia coriacea samples contained nutritionally useful quantities of most of the essential amino acids. The total essential amino acids (TEAA) (with His) were 31.14 and $34.40 \mathrm{~g} / 100 \mathrm{~g}$ crude protein for the Artocarpus altilis and Bucchholzia coriacea samples, respectively. The first limiting amino acid was Met + Cys (TSAA) for all the samples and calculated isoeletric points ( $\rho l)$ were 3.52 and 4.05 for Artocarpus altilis and Bucchholzia coriacea, respectively.
\end{abstract}

Keyword : Proximate; minerals; amino acids; Artocarpus altilis and Bucchholzia coriacea

\section{Introduction}

In developing countries like Nigeria, numerous wild edible plants are exploited as food sources; hence they provide an adequate level of nutrition to the inhabitants (Aberoumand, 2009). Breadfruit (Artocarpus altilis) belongs to the Mulberry family Moraceae. In Nigeria, the breadfruit is regarded as the poor man's substitute for yam (Dioscorea esculenta and D. cayenensis), because it is used in several traditional food preparations of yam, but costs less than one third the cost of procuring yam at the market. It is used in soft and stiff porridge dishes, boiled as yam, fried as chips and roasted as roast yam (Mayaki et al., 2003). It's a rich source of carbohydrates, fiber, vitamins (vitamin C) and minerals (potassium) (Graham and Negron de Bravo, 1981). Breadfruit has a considerable untapped potential as a nutritious food particularly among the low-income groups of the society in developing countries, and has an advantage over cereals and roots as it yields two or three times as much minerals and vitamins as cereals and roots (Amusa et al., 2002). Plants serve as an indispensable constituent of human diet supplying the body with minerals salts, vitamins and certain hormone precursors, in addition to protein and energy (Oyenuga and Fetuga, 1975). The use of plants in traditional medicine has a long history in the life of a man, and it remains the mainstay of primary health care in most of the developing countries. Plant-based medicines are used by over $60 \%$ of the world population; in both developing and developed countries where modern medicines are predominantly used (Mythilypriya et al., 2007). In African countries large proportions of the population depends solely on herbal medicines for its primary health care needs. However, seeds have nutritive and calorific values which make them necessary in diets (Odoemelam, 2005), and among these plant seeds are the seeds of Buccholzia coricea popularly known as "Wonderful kola". Buccholzia coricea is a perennial plant which grows as a tree. 
It belongs to the family Capparaceae and is known as uworo, owi, and uke by Yoruba, Edo and Ibo people in Nigeria respectively (Quattrochi-Umbeto, 2007). The plant parts commonly eaten are the seeds which are either cooked or eaten raw. Bucchholzia coriacea is a brain food, which promotes memory, useful in the treatment of hypertension and prevents premature aging. It is evident in some parts of Africa that wonderful kola has the ability to stop migraine headache (Ibrahim and Fagbohun, 2012). The Bucchholzia coriacea plants serves as food and medicine in many parts of African countries, hence, gave the plant a common name wonderful kolanut Ijarotimi et al., 2015). Over the years, breadfruits and wonderful kola have been food in many parts of the world. In Nigeria, the seeds are native to south - western, south - south and south - eastern part; commonly eaten raw or cooked. It had been claimed that they possess nutritional values. However, this work focuses on finding the nutritive contents of these seeds as sources of food. The knowledge obtained from the study will aid policy-makers in the agriculture sector and food industry to making informed decisions aimed at broadening the nation's food security basket.

\section{Materials and methods}

\section{Samples collection and treatment}

The fresh fruits of wonderful kola (Buccholzia coriacea) and breadfruit (Artocarpus altilis) were purchased from Ogoja market in Ogoja local government area of Cross River State, Nigeria and transported to the laboratory for treatment and analyzes. Four seeds each were removed from the fruits of Buccholzia coriacea and Artocarpus altilis, washed, peeled and dried in an oven at $45^{\circ} \mathrm{C}$ for $72 \mathrm{~h}$. The dried seeds were ground into powder separately using a food blender, sieved though a $250 \mu \mathrm{m}$ and then stored in airtight containers for further analysis.

\section{Proximate analysis}

The ash, moisture, crude fat, crude protein ( $\mathrm{N} x$ 6.25), crude fibre and carbohydrate (by difference) were determined in accordance with the methods of AOAC (1995). All proximate analyses of the sample flour were carried out in triplicate and reported in percentage. All chemicals were of Analar grade.

\section{Mineral analysis}

The potassium and sodium were determined using a flame photometer (Model 405, Corning UK). Phosphorus was determined by Vanadomolybdate colourimetric method (James, 1996). All other metals were determined by atomic absorption spectrophotometer (Perkin-Elmer Model 403, Norwalk CT). All the minerals determined were reported in $\mathrm{mg} / 100 \mathrm{~g}$ sample.
Determination of isoelectric point (pI), quality of dietary protein and predicted protein efficiency ratio ( $P-P E R)$

The predicted isoelectric point was evaluated according to Olaofe and Akintayo (2000):

$$
\mathrm{plm}=\sum_{(\mathrm{i}=1)}^{(\mathrm{n}=1)} \mathrm{pliXi}
$$

where:

$\mathrm{pIm}=$ the isoelectric point of the mixture of amino acids;

pIi $=$ the isoelectric point of the ith amino acids in the mixture;

$\mathrm{Xi}=$ the mass or mole fraction of the amino acids in the mixture.

The quality of dietary protein was measured by finding the ratio of available amino acids in the sample protein compared with the needs expressed as a ratio. Amino acid score (AAS) was then estimated by applying the FAO/WHO (1991) formula:

$$
A A S=\frac{\mathrm{mg} \text { of amino acid in reference protein }}{\mathrm{mg} \text { or amino acid in } 1 \mathrm{~g} \text { of test protein }} \times 100 / 1
$$

The predicted protein efficiency ratio (P-PER) of the seed sample was calculated from their amino acid composition based on the equation developed by Alsmeyer et al. (1974) as stated thus; P-PER $=-0.468+0.454(\mathrm{Leu})-0.105$ (Tyr).

\section{Statistical analysis of the samples}

The proximate and mineral values were obtained with \pm standard deviations of triplicate determinations. The fatty acid values were obtained by multiplying crude fat value of each sample with a factor of 0.8 (i.e. crude fat $\mathrm{x} 0.8$ is corresponding to fatty acids value. The energy values were calculated by adding up the carbohydrate x $17 \mathrm{~kJ}$, crude protein $\mathrm{x} 17 \mathrm{~kJ}$ and crude fat $\mathrm{x} 37 \mathrm{~kJ}$ for each of the samples (Kilgore, 1987).

\section{Results and discussion}

The proximate composition, calculated metabolisable energy and fatty acid values of the studied samples are presented in Table I. The moisture content of Artocarpus altilis $(5.91 \%)$ and Buccholzia coricea (5.67\%) were generally low and within the recommended dietary allowance (RDA) $(3-10)$ (NRC, 1989). The low values of moisture ensured a long shelf life of the samples without microbial spoilage. The 
crude fat content of Artocarpus altilis and Buccholzia coricea were 4.42 and $2.76 \%$, respectively. None of the studied sample is qualified as oil-rich plant when compared with soybean (22.8 and 23.5\%) (Paul and Southgate, 1978; Salunke et al., 1985) pumpkin seed (49.2 and 47.0\%) (Aisegbu, 1989; Fagbemi and Oshodi, 1991) and C. vulgaris (47.9-51.1\%) (Ige et al., 1984). Plant foods that provide more than $12 \%$ of their calorific value from protein have been shown to be good sources of protein (Ali, 2009). This shows that both Artocarpus altilis (12.27 \%) and Buccholzia coricea $(14.78 \%)$ may be good sources of protein. The protein contents obtained from the samples are comparable to that of kersting's groundnut (12.90\%) (Aremu et al, 2006a).
Artocarpus altilis and Buccholzia coricea may be advantageous since high fibres content of foods help in digestion, prevention of colon cancer and in the treatment of diseases such as obesity, diabetes and gastrointestinal disorders (UICC/WHO, 2005). The carbohydrate content revealed in Table I, are highly compared to the carbohydrate content in $T$. occidentalis $(8.0 \%)$ (FAO, 1986), pineapple $(12.30 \%)$ and orange (9.82\%) (Aremu and Olonisakin, 2004). High fatty acid value in oil indicates that the oil may not be suitable for use in cooking (edibility), but however, be useful for industrial purposes, therefore oil obtained from Artocarpus altilis and Buccholzia coricea will be suitable for use in cooking because of it low acid value. The high

Table I. Proximate composition (\%) ${ }^{\mathrm{a}}$ of Artocarpus altilis and Bucchholzia coriacea

\begin{tabular}{|c|c|c|}
\hline Parameter & Artocarpus altilis & Bucchholzia \\
\hline Moisture & $5.91 \pm 0.06$ & $5.67 \pm 0.11$ \\
\hline Ash & $4.39 \pm 0.12$ & $5.13 \pm 0.08$ \\
\hline Crude fat & $4.42 \pm 0.13$ & $2.76 \pm 0.22$ \\
\hline Crude protein & $12.27 \pm 0.56$ & $14.78 \pm 0.32$ \\
\hline Crude fibre & $7.10 \pm 0.11$ & $6.27 \pm 0.06$ \\
\hline Carbohydrate $^{\mathbf{b}}$ & $65.91 \pm 0.72$ & $65.39 \pm 0.13$ \\
\hline Fatty acid ${ }^{\mathbf{c}}$ & $3.43 \pm 0.11$ & $2.21 \pm 0.18$ \\
\hline Energyd & $1492.60 \pm 7.53$ & $1465.01 \pm 4.73$ \\
\hline
\end{tabular}

${ }^{\text {a }}$ Mean values \pm standard deviations of triplicate determinations; ${ }^{\mathbf{b}}$ Carbohydrate percent calculated as the $(100-$ total of other components); ${ }^{\mathbf{c}}$ Calculated fatty acid ( $0.8 \mathrm{x}$ crude fat $) ;{ }^{\mathrm{d}}$ Calculated metabolizable energy $(\mathrm{kJ} / 100 \mathrm{~g})$ $($ protein $\times 17+$ fat $\times 37+$ carbohydrate $\times 17)$

Ash content is a measure of mineral content of food. The result indicates that there are more minerals in Buccholzia coricea $(5.13 \%)$ than the Artocarpus altilis (4.39\%). Ash content of these samples is higher than those reported for some leafy vegetables such as Solanium nodiflorum (ogumo) (2.67\%) (Adeleke and Abiodun, 2010). Both samples had ash content slightly lower than the lowest RDA value of $6 \%$. Crude fibre is a significant component in the body. It increases stool bulk and decreases the time that waste materials spend in the gastrointestinal tracks (Aremu et al., 2015). Crude fibre in the diet consists mostly of the plant polysaccharides that cannot be digested by human dietary enzymes such as cellulose, hemicelluloses and some materials that make up the cell wall (Southland, 1975). The fibre content obtained in Artocarpus altilis $(7.10 \%)$ and Buccholzia coricea $(6.27 \%)$ more higher than that of $T$. triangulare $(2.40 \%), T$. occidentalis $(1.7 \%)$ and C. argentea $(1.8 \%)$ (Akachukwu and Fawusi, 1995) and apple $(3.62 \%)$ (Fasoyiro et al., 2005). Therefore, the consumption of metabolizable energy values obtained showed that the samples had energy concentration that compares fairly with those reported for some legumes such as bambara groundnut $(1691.3 \mathrm{~kJ} / 100 \mathrm{~g})$, kersting's groundnut $(1692.9 \mathrm{~kJ} / 100 \mathrm{~g})$ and cranberry beans $(1651.7 \mathrm{~kJ} / 100 \mathrm{~g}$ ) (Aremu et al., 2006a), red kidney bean (1678.4 kJ/100 g) (Audu and Aremu, 2011).

The mineral composition in $\mathrm{mg} / 100 \mathrm{~g}$ of Artocarpus altilis and Buchholzia coriacea are presented in Table II. The result showed that toxic metals such as lead, cadmium, arsenic and chromium were not determined. The sodium content of Artocarpus altilis and Buchholzia coriacea were 67.19 $\mathrm{mg} / 100 \mathrm{~g}$ and $58.18 \mathrm{mg} / 100 \mathrm{~g}$, respectively. Sodium is an important mineral that assist in the regulation of body fluid and in the maintenance in the body tissue (Aremu et al., 2012). The world health organization (WHO) recommended intake of sodium per day is $500 \mathrm{mg}$ for adult and $400 \mathrm{mg}$ for children (WHO, 1973). The result indicates that sodium content of Artocarpus altilis and Buchholzia coriacea were 
Table II. Mean mineral composition (mg/100 g sample) $)^{\mathrm{a}}$ of Artocarpus altilis and Buchholzia coriacea seeds

\begin{tabular}{ccc}
\hline Mineral & Artocarpus artilis & Bucchholzia coriacea \\
\hline Sodium & $67.19 \pm 0.20$ & $58.18 \pm 0.01$ \\
Calcium & $49.58 \pm 0.05$ & $144.85 \pm 0.03$ \\
Potassium & $658.42 \pm 0.011$ & $369.64 \pm 0.02$ \\
Magnesium & $206.16 \pm 0.08$ & $115.91 \pm 0.10$ \\
Phosphorus & $382.55 \pm 0.16$ & $261.38 \pm 0.45$ \\
Iron & $2.19 \pm 0.01$ & $5.83 \pm 0.31$ \\
Copper & $0.61 \pm 0.10$ & $0.81 \pm 0.02$ \\
Zinc & $3.82 \pm 0.10$ & $0.22 \pm 0.10$ \\
Sodium/Potassium & 0.10 & 0.16 \\
Calcium/Phosphorus & 0.13 & 0.55 \\
Calciun/Magnesium & 0.24 & 1.25 \\
\hline
\end{tabular}

${ }^{\mathrm{a}}$ Mean values \pm standard deviation of triplicate determinations

Table III. Amino acid composition of Artocarpus altilis and Bucchholzia coriacea (g/100 g crude protein)

\begin{tabular}{|c|c|c|}
\hline Amino acid & Artocarpus altilis & Bucchholzia coriacea \\
\hline Lysine (Lys) ${ }^{\mathbf{h}}$ & 3.35 & 4.03 \\
\hline Histidine (His) ${ }^{\mathbf{h}}$ & 2.20 & 2.36 \\
\hline Arginine $(\operatorname{Arg})^{\mathbf{h}}$ & 5.16 & 5.76 \\
\hline Aspartic acid (Asp) & 7.84 & 8.31 \\
\hline Threonine $(\mathrm{Thr})^{\mathbf{h}}$ & 2.99 & 3.44 \\
\hline Serine (Ser) & 1.29 & 3.18 \\
\hline Glutamic acid (Glu) & 9.99 & 11.35 \\
\hline Proline (Pro) & 2.84 & 3.35 \\
\hline Glycine (Gly) & 3.32 & 3.89 \\
\hline Alanine (Ala) & 3.83 & 4.43 \\
\hline Cystine (Cys) & 0.78 & 0.84 \\
\hline Valine $(\text { Val })^{\mathbf{h}}$ & 3.45 & 4.00 \\
\hline Methionine (Met) ${ }^{\mathbf{h}}$ & 0.91 & 1.33 \\
\hline Isoleucine (Ile) $^{\mathbf{h}}$ & 3.01 & 2.85 \\
\hline${\text { Leucine }(\mathrm{Leu})^{\mathbf{h}}}^{\mathbf{h}}$ & 6.80 & 7.09 \\
\hline Tyrosine (Tyr) & 2.58 & 3.09 \\
\hline Phenylalanine (Phe) $)^{\mathbf{h}}$ & 3.37 & 3.54 \\
\hline Isoelectric point (pI) & 3.52 & 4.05 \\
\hline P-PER & 2.35 & 2.43 \\
\hline Leu/Ile & 2.26 & 2.49 \\
\hline
\end{tabular}

${ }^{\text {h}}$ Essential amino acid; P-PER $=$ Predicted protein efficiency ratio 
below WHO recommended standard. Therefore Artocarpus altilis and Buchholzia coriacea cannot be regarded as rich source of sodium. The iron compositions were $2.19 \mathrm{mg} / 100 \mathrm{~g}$ for Artocarpus altilis and $5.83 \mathrm{mg} / 100 \mathrm{~g}$ for Buchholzia coriacea. Iron facilitates the oxidation of carbohydrates, proteins and fat (Aremu et al., 2012). It's also required for blood formation and normal functioning of the central nervous system (Adeyeye and Fagbohun, 2005). The RDA of iron in both adult and children is $10 \mathrm{mg} / 100 \mathrm{~g}$ and $15 \mathrm{mg} / 100$ $\mathrm{g}$ for female adult per day (Delvin, 1992). Iron deficiency, anemia is mostly found among children, pregnant and menstruating women. This is reflected in dietary intake and increased frequency of achlorhydria (Delvin, 1992). The copper contents of Artocarpus altilis and Buchholzia coriace were $0.62 \mathrm{mg} / 100 \mathrm{~g}$ and $0.81 \mathrm{mg} / 100 \mathrm{~g}$. Report has shown that copper is required in the body for enzyme production and biological electron transport (Aremu et al., therapeutically to promote wound healing and may be of some use in treating gastric ulcers (Goyer, 1997). Table II also shows that Artocarpus altilis and Buchholzia coriacea contained $3.82 \mathrm{mg} / 100 \mathrm{~g}$ and $0.22 \mathrm{mg} / 100 \mathrm{~g}$ zinc respectively. The result showed that Artocarpus altilis and Buchholzia coriacea were not good source of zinc since it is less than that the RDA (15 mg/100 g) for zinc. Copper and zinc are considered the less concentrated minerals in Artocarpus altilis $(0.61 \mathrm{mg} / 100 \mathrm{~g})$ and Buchholzia coriacea $(0.22 \mathrm{mg} / 100 \mathrm{~g})$, respectively. The most abundant mineral in both samples of Artocarpus altilis and Buchholzia coriacea were potassium 658.42 and $369.64 \mathrm{mg} / 100 \mathrm{~g}$, phosphorus 382.55 and $261.38 \mathrm{mg} / 100 \mathrm{~g}$, magnesium 206.16 and 115.91 $\mathrm{mg} / 100 \mathrm{~g}$ and calcium 49.58 and $144.85 \mathrm{mg} / 100 \mathrm{~g}$, respectively. Magnesium is an activator of many enzyme systems and maintains the electrical potential in nerves. Magnesium is required for all reactions involving ATP

Table IV. Concentrations of essential, non-essential, acid, neutral, sulphur, aromatic, etc. (g/100g crude protein) of Artocarpus altilis and Bucchholzia coriacea

\begin{tabular}{lcc} 
Amino acid description & Artocarpus altilis & Bucchholzia coriacea \\
\cline { 2 - 3 } Total amino acid (TAA) & 63.61 & 72.84 \\
Total non-essential amino acid (TNAA) & 32.47 & 38.44 \\
\% TNAA & 51.05 & 52.77 \\
Total essential amino acid (TEAA) & & \\
With histidine & 31.14 & 34.40 \\
Without histidine & 28.94 & 32.04 \\
$\quad \%$ TEAA & & \\
With histidine & 48.95 & 47.23 \\
Without histidine & 45.50 & 43.99 \\
Essential alphatic amino acid (EAAA) & 16.25 & 17.38 \\
Essential aromatic amino acid (EArAA) & 3.37 & 3.54 \\
Total neutral amino acid (TNAA) & 35.17 & 41.03 \\
$\quad \%$ TNAA & 55.29 & 56.33 \\
Total acidic amino acid (TAAA) & 17.83 & 19.66 \\
\% TAAA & 28.03 & 26.99 \\
Total basic amino acid (TBAA) & 10.61 & 12.15 \\
$\quad$ TBAA & 16.68 & 16.68 \\
Total sulphur amino acid (TSAA) & 1.70 & 2.17 \\
$\quad \%$ cystine in TSAA & 45.88 & 38.71 \\
\hline
\end{tabular}

2012). Zinc is an essential element for all animals including human beings and it plays an important physiological role. Zinc is also associated with many enzymes system, both as metallo-enzyme and enzymes activator (Sarma, 2006). Over 100 zinc metallo-enzymes have been described to date, including a number of regulatory proteins and both RNA and DNA polymerase (Delvin, 1992). Zinc is occasionally used
(Adenosine Triphosphate). ATP supplies the energy for physical activity by releasing energy stored in phosphate bonds. Report has shown that magnesium may help support mineral bone density in elderly women and men (Stendig-Lindberg et al., 1993). It has been reported that calcium in conjunction with phosphorus, magnesium, manganese, vitamin $\mathrm{A}, \mathrm{C}$ and $\mathrm{D}$, chlorine and protein are all 
involved in bone formation (Fleck, 1976). Modern diets that are rich in phosphorus may promote the loss of calcium to phosphorus ratio. This has led to the concept of calcium to phosphorus ratio $(\mathrm{Ca} / \mathrm{P})$. The $\mathrm{Ca} / \mathrm{P}$ ratio of Artocarpus altilis and Buchholzia coriacea flour was found to be 0.13 and 0.55 . Food is considered good if $\mathrm{Ca} / \mathrm{P}$ ratio is above 1 and poor if the ratio is less than 0.5 . While $\mathrm{Ca} / \mathrm{P}$ ratio above 2 helps to increase the absorption of calcium in the small intestine. The $\mathrm{Na} / \mathrm{K}$ ratio was found to be 0.10 for Artocarpus altilis and 0.16 Buchholzia coriacea. This ratio is of great significant and concern for the prevention of high blood pressure. $\mathrm{Na} / \mathrm{K}$ ratio less than 1 is recommended. Thus, consumption of Artocarpus altilis and Buchholzia coriacea seeds would probably reduce high blood disease because it had $\mathrm{Na} / \mathrm{K}$ ratio less than 1. The value of $\mathrm{Ca} / \mathrm{Mg}$ in Artocarpus altilis and Buchholzia coriacea were 0.24 and 1.25 , respectively. The recommended value of $\mathrm{Ca} / \mathrm{Mg}$ ratio is 1.00 (NRC, 1989). Consequently Buchholzia coriacea will meet the required RDA for $\mathrm{Ca} / \mathrm{Mg}$ ratio while Artocarpus altilis is below 1.00 . Table III. shows the amino acid profile of the four legume seeds. Leu was the most concentrated (6.80 and $7.09 \mathrm{~g} / 100 \mathrm{~g}$ cp) essential amino acid while the most concentrated amino acid was glutamic acid (9.99 and $11.35 \mathrm{~g} / 100 \mathrm{~g} \mathrm{cp}$ ) in the Artocarpus altilis and Buccholzia coricea samples, respectively. Tryptophan was not determined. The value of leucine obtained in this study agrees and compares favourably with values obtained by some workers on studies of some Nigerian legumes (Oshodi et al., 1998). The calculated isoelectric point $(\mathrm{\rho l})$ varied between 3.52 (Artocarpus altilis) and 4.05 (Buccholzia coricea). This is useful in predicting the $\rho 1$ for protein in order to enhance a quick precipitation of protein isolate from biological samples (Olaofe and Akintayo, 2000).

The nutritive value of a protein depends primarily on the capacity to satisfy the needs for nitrogen and essential amino acids (Pellet and Young, 1980). The total essential amino acid (TEAA) values (with His) ranged between $47.23 \%$ in Buccholzia coricea and $48.95 \%$ in Artocarpus altilis (Table IV). These are comparable with values obtained from selected oil seeds which ranged between 33.3 and $53.6 \%$ (Olaofe et al., 1993) and soybean (46.5\%) (Aisegbu, 1989), suggesting that these studied samples which are readily available in the south-south and south-east of Nigeria can be used as food supplements. Table IV also depicts the percent of total acid amino acids (TAAA) which was found to be greater than the percent of total basic amino acids (TBAA) in all the samples indicating that the protein is probably acid in nature (Aremu et al., 2011). The concentrations of total sulphur amino acids (TSAA) which ranged between 1.70 and $2.17 \mathrm{~g} / 100 \mathrm{~g} \mathrm{cp}$ in Artocarpus altilis and Buccholzia coricea respectively are lower than the $5.8 \mathrm{~g} / 100 \mathrm{~g}$ cp recommended for infants (FAO/WHO/UNU, 1985). Results of the amino acid scores are shown in Table V. Buccholzia coricea sample rated high when compared with Artocarpus altilis sample. However, with exception of Leu and Phe + Tyr in Buccholzia coricea, the essential amino acid contents were lower than the FAO/WHO (1991) recommended pattern. Thus by implication, dietary formula based on these plants will require some essential amino acids supplementation such as Met, Cys, Val, Ile, Thr and Lys. It has been reported that EAAs most often acting in a limiting capacity are Met (and Cys), Lys and Try (Aremu et al, 2006b,c). In this present study, Met + Cys (TSAA) were the first limiting amino acids in all the samples while Lys and Ile were the second limiting amino acids in Artocarpus altilis and Buccholzia coricea, respectively.

\section{Conclusion}

The present study showed that the two different plant seeds (Artocarpus altilis and Buccholzia coricea) were good

Table V. Amino acid scores of Artocarpus altilis and Bucchholzia coriacea based on FAO/WHO standards

\begin{tabular}{cccccc}
\hline EAA & $\begin{array}{c}\text { PAAESP g/100g } \\
\text { protein }\end{array}$ & \multicolumn{2}{c}{ Artocarpus altilis } & \multicolumn{2}{c}{ Bucchholzia coriacea } \\
& EAAC & AAS & EAAC & AAS \\
\hline Ile & 4.0 & 3.01 & 0.75 & 2.85 & 0.71 \\
Leu & 7.0 & 6.80 & 0.97 & 7.09 & 1.01 \\
Lys & 5.5 & 3.25 & 0.59 & 4.03 & 0.73 \\
Met + Cys (TSAA) & 3.5 & 1.70 & 0.49 & 2.17 & 0.62 \\
Phe + Tyr & 6.0 & 5.95 & 0.99 & 6.63 & 1.11 \\
Thr & 4.0 & 2.99 & 0.75 & 3.44 & 0.86 \\
Trp & 1.0 & nd & na & nd & na \\
Val & 5.0 & 3.45 & 0.69 & 4.00 & 0.80 \\
Total & 36.0 & 27.15 & 5.23 & 30.21 & 5.84 \\
\hline
\end{tabular}

EAA $=$ Essential Amino Acid; PAAESP = Provisional Amino Acid (Egg) Scoring Pattern; EAAC = Essential Amino Acid Composition; AAS = Amino Acid Score; $n d=$ Not determined; na = Not applicable 
sources of essential minerals and contained nutritionally useful quantities of most of the essential amino acids however dietary formula based on them may require some essential amino acids supplementation such as Ile, Lys, TSAA, Thr and Val.

\section{Acknowledgement}

The authors are thankful to Dr. T. O. Ojobe of Zoology Laboratory of University of Jos, Nigeria for providing technical assistance in the analysis of amino acids and Miss Maria Obegu of Faculty of Pure and Applied Sciences, Federal University Wukari, Nigeria for obtaining the samples from South - South part of the country.

\section{References}

Aberoumand A (2009), Nutrition evaluation of edible Portulaca oleracia as plant food, Food Anal Methods 2: 204-207. DOI: 10.1007/s12161-008-9049-9

Adeleke RO and Abiodun OA (2010), Chemical Composition of Three Traditional Vegetables in Nigeria, Pakistan Journal of Nutrition 9(9): 858-860. DOI: $10.3923 /$ pjn.2010.858.860

Adeyeye EI and Fagbohun ED (2005), Proximate, mineral and phytates profiles of some selected species in Nigeria, Pak. J. Sci. Ind. Res. 48: $14-22$.

Aisegbu JE (1989), Some biochemical evaluation of fluted pumpkin seed, Journal of the Science Food and Agriculture 40:15-25. DOI: 10.1002/jsfa.2740400207

Akachukwu CO and Fawusi MOA (1995), Growth characteristic, yield and nutritive values of water leaf, Discovery and Innovations 7(2): 163 - 172.

Ali A (2009), Proximate and mineral composition of the marchubeh (Asparagus officinalis), World Dairy and Food Science 4(2): 142 - 149.

Alsmeyer RH Cunningham AE and Happich ML (1974), Equation to predict (PER) from amino acid analysis, Food Technology 28: $34-38$.

Amusa NA Kehinde A and Ashaye OA (2002), Bio-deterioration of breadfruit (Artocapus conununis) in storage and it effect on nutritional composition, African J. Biotech. 1: 57-60.

AOAC (1995), Official Methods of Analysis. 16 $6^{\text {th }}$ Ed., Association of Offical Analytical Chemists, Washington DC, USA.

Aremu MO, Oko OJ, Ibrahim H, Basu SK, Andrew C and Ortutu SC (2015), Compositional evaluation of pulp and seed of blood plum (Haematostaphis barteri), a wild tree found in Taraba State, Nigeria, Advances in Life Science and Technology 33: $9-17$.
Aremu MO and Olonisakin A (2004), Comparative analysis of L-ascorbic acid in fruit juices and juice beverages, Journal of Ultra Science 16(1): 9 - 14. DOI: 10.1016/S0021-9673(02)01345-6

Aremu MO, Nweze CC and Alade P (2011), Evaluation of protein and amino acid composition of selected spices grown in the middle belt region of Nigeria, Pak. J. Nutri. 10(10): 991 - 995.

Aremu MO, Olaofe O and Akintayo ET (2006a), Mineral and amino acid compostion of two varieties of bambara groundnut (Vigna subterranean) and Kersting's groundnut (Kerstingiella geocarpa) flour, Int. J. Chem. 16: $57-64$

Aremu MO, Olaofe O and Akintayo ET (2006c), Chemical composition and physicochemical characteristics of two varieties of bambara groundnut (Vigna subterrenean) flours, J. Applied Sciences 6(9): 1900 1903. DOI: $10.3923 /$ jas.2006.1900.1903

Aremu MO, Olonisakin A, Atolaiye BO and Ogbu CF (2007), Some nutritional composition and functional properties of Prosopis africana, Bangladesh J. Sci. Ind. Res. 42(3): 269 - 280. DOI: 10.3329/bjsir.v42i3.665

Aremu MO, Salau RB. and Suleiman AA (2012), Compositional evaluation of young shoot of deleb palm (Borassus aethiopum, MART) and white yam (Dioscorea rotundata) flours, Int. J. Chem. Sci. 5(2): $168-174$.

Aremu MO, Olaofe O and Akintayo ET (2006b), Compositional evaluation of cowpea (Vigna unguiculata) and scarlet runner bean (Phaseolus Cocineus) varieties grown in Nigeria, J. Food, Agric and Enviro 4(2): 39-46

Audu SS and Aremu MO (2011), Effects of processing on chemical composition of red kidney bean (Phaseolus Vulgaries L.) flour, Pak. J. Nutri. 10(11): 1069-1075

Delvin TM (1992), Textbook of Biochemistry with Clinical Correlation. $3^{\text {rd }}$ Ed., John Willy \& Sons Inc., $\quad p p \quad 138 \quad-\quad$ 147. 10.1016/0014-5793(93)80467-9

Fagbemi TN and Oshodi AA (1991). Chemical composition and functional properties of full fat fluted seed flour, Nigerian Food Journal 9: 26-32. DOI: 10.1002/jsfa.2740590308

FAO (1986), Compositional analysis method in manuals of food quality control, Food 7: $203-232$.

FAO/WHO (1991), Protein quality evaluation report of joint FAO/WHO expert consultative FAO, Food and Nutrient. 
FAO/WHO/UNU (1985), Energy and protein requirements, Technical report series No. 724, Geneva.

Fasoyiro SB, Babalola SO and Owosibo T (2005), Chemical Composition and Sensory Quality of Fruit-Flavoured Roselle (Hibiscus sabdariffa) Drinks, World Journal of Agricultural Sciences 1(2): 161-164.

Fleck H (1976), Introduction to Nutrition, $3^{\text {rd }}$ Ed., Macmillan New York, pp. $207-219$.

Goyer AR (1997), Toxic and essential metal interaction, Annual Review of Nutrition 17: 37-50. DOI: 10.1146/annurev.nutr.17.1.37

Graham HD and Negron de Bravo E (1981), Composition of the breadfruit, J Food Sci. 46: 535-539. DOI: 10.1111/j.1365-2621.1981.tb04904.x

Ibrahim TA and Fagbohun ED (2012), Phytochemical and nutritive quality of dried seeds of Bucchholzia coriacea, Greener Journal of Physical Sciences 2: 185-191.

Ige MM, Ogunsua AO and Oke OL (1984), Functional properties of the proteins of some Nigeria oil seeds, camphor seeds and three varieties of melon seeds, $J$. Agricultural and Food Chemistry 32: 822-825.

Ijarotimi OS, Nathaniel FT and Faramade OO (2015), Determination of chemical composition, nutritional quality and anti-diabetic potential of raw, blanched and fermented wonderful kola (Bucholzia coriacea) seed flour, J. Hum Nutr Food Sci. 3(2): 1060.

James CS (1996), Analytical Chemists of Foods. New York NY, Chapman and Hall.

Kilgore, O. F. G. (1987). Mastering Nutrients, Macmillan Education Ltd. London, UK, pp 95 - 96.

Mayaki OM, Akingbala, OJ, Baccus-Taylor GSH and Thomas S (2003), Evaluation of breadfruit (Artocarpus communis) in traditional stiff porridge foods, Food Agric. Environ. 1(2): 54-59.

Mythilypriya R, Shanthi P and Sachdanandam P (2007), Oral acute and subacute toxicity studies with Kalpa amruthaa, a modified indigenous preparation, on rats, J. Health Sci. 53: 351-358.

NRC (National Research Council) (1989), Recommended Dietary Allowance, $10^{\text {th }}$ Ed., National Academy press, Washinghton DC, USA.

Odoemelam SA (2005), Proximate Composition and Selected Physicochemical Properties of the Seeds of African Oil Bean (Pentaclethra marcrophylla), J. Nutr. 4: 382-383.
Olaofe O and ET Akintayo (2000), Prediction of isoelectric points of legume and oil seed proteins from amino acid composition, J. Technoscience 4: 49-53.

Olaofe O, Umar YO and Adediran GO (1993), The effect of nematicides on the nutritive and functional properties of cowpea seeds, Food Chem. 46: 337-342.

Oshodi AA, Esuoso KO and Akintayo ET (1998), Proximate and amino acid composition of some under-utilized Nigerian legume flour and protein concentrates, $L a$ Rivista Itatiana Delle Sostanze Grasse 75: 409-412.

Oyenuga VA and Fetuga BL (1975), First Nutritional Seminar on Fruits and Vegetables. In: Proc and Recom and Papers by NIHORT, Ibadan.

Paul AA and Southgate DAT (1978), McCance and Widdowson's The Composition of Foods, $4^{\text {th }}$ Ed., Her Majesty's Stationary Office, London, UK, pp. 227-228.

Pellet PL and Young VR (1980), Nutritional evaluation of protein foods: Report of a working group sponsored by the International Union of Nutritional Sciences and the United Nations University World Hunger Programme. The United Nations University.

Quattrochi-Umbeto FLS (2007), World Dictionary of Plant Names-Common names, Scientific names, Eponyms, Synonyms and Entomology, C.R.C. Press, pp: 367-368.

Salunke DK, Kadam SS and Chavan JK (1985), Postharvest Biotechnology of Food Legumes, CRC Press, Boca Raton, FL.

Sarma LS (2006), Studies of Zinc (II) in pharmaceutical and biological spectrohotometry using pyridoxal4phenyl3thiosemicarbazone as chelating reagent, J. Braz. Chem. Soc. 17(3): 463 - 472.

Southland WM (1975), Biochemistry of Nutrition, Church Hill Livingstone, New York, pp 471 - 473.

Stendig-Lindberg G, Tepper R and Liechter I (1993), Tabecular bone density in a two year controlled trial peroral magnesium in osteoporosis, Magnesium Research 6(2): 155 - 63.

UICC/WHO (2005), Global action against cancer, UICC and WHO Publications Department, Geneva.

WHO, World Health Organization (1973), Trace elements in human nutrition, WHO Technical Report Series No: 532 Geneva. 